\title{
Commentary
}

\section{A General Assessment of the Developments in the Black Sea Region since 1990}

\author{
Göknil Erbaş*
}

The Black Sea region is increasingly becoming a priority on the international agenda since the collapse of Soviet Union. Almost twenty years ago, it did not even appeared on many political maps. ${ }^{1}$ It was considered a borderline between NATO and its member in the region Turkey and the Warsaw Pact. However, in the contemporary international politics, Black Sea is one of the most salient regions where balance of power has changed and new geopolitical discourses emerged. Many important factors contributed to this development. First of all, especially in the last ten years, the Black Sea as a regional project represents new security and cooperation patterns in the new international system. New security patterns, such as energy and environment, are now in the gaining more importance. Beside these systemic transformations, political conditions in the Black Sea region have also changed. While there were only two players in the region before the collapse of the Soviet Union, Today, there are five littoral states.

\footnotetext{
* Göknil Erbaş is a PhD candidate in the Department of International Relations, Ankara University, Ankara, Turkey.

${ }^{1}$ Sergei Konoplyov, “US Interests in the Wider Black Sea Region”, III. Black Sea International Symposium, Black Sea Beneficiaries, KARASAM, Giresun, Turkey, 4-6 August 2010, p. 31.
} 
The notion of the Black Sea as a "region" first emerged in the early 1990s, and further debates whether or not it qualifies as a region culminated within the next decade. As expected, the disappearance of the Cold War barriers enabled the Black Sea countries to enhance bilateral and multilateral relations. In this context, regional cooperation was seen as the most considerable opportunity for the new states. The first initiative to create the Black Sea region is the foundation of the Organization of the Black Sea Economic Cooperation (BSEC) in which Turkey played a major role. BSEC constitutes a platform for littoral states to gain constitutional experience, because the new littoral states of Black Sea were economically and politically weak during the first half of the 1990s. These states have diverse political systems; some of them have communist pasts and a lack of democratic experience have reversed democratization processes in many cases. The first advantage of the BSEC is to be a platform for democratic and liberal constitutional process. This organization would contribute to the transformation of the former socialist economies and the integration of the regional economies with the global markets. Secondly, the Black Sea region states "aim to ensure that the Black Sea becomes a sea of peace, stability and prosperity, striving to promote friendly and good neighborly relations" as stated in the BSEC declaration of 1992 . $^{2}$ This aim has been promoted and developed by the BSEC in the 1990s.

Though the BSEC gradually developed in the first twenty years after its foundation and achieved considerable success in a number of fields, there are several obstacles to fostering cooperation that limit the ability of the organization to widen and deepen its functions. The economic and political problems that persist in the BSEC states hamper effective cooperation. Apart from this, the diversity of member states in political, economic,

\footnotetext{
${ }^{2}$ Organization of the Black Sea Economic Cooperation, 25 June 1992, Summit Declaration on Black Sea Economic Cooperation,

$<$ bttp:/ / wmw.bsecorganization.org/documents.aspx?ID =Summit_Declarations $2 \cdot D I D=26$ $>$.
} 
A General Assessment on the Developments in the Black Sea Region

cultural, and military terms and the multiplicity of national interests which intersect with each other in many instances slow down the development of cooperation. However, BSEC was clearly the first initiative that tried to create a common perspective in the Black Sea area. Along with the BSEC, both NATO and the EU raised the salience of the Black Sea region by enlarging towards the East during the last decade.

The 1990s have witnessed a transition process to liberal economic systems in the Black Sea region. After the collapse of the Soviet Union, despite its economic, military and social difficulties Russia declared this region its "near abroad" meaning that it has taken her traditional geopolitical perspective towards the Black Sea region. Initially the inclination of Ukraine and Georgia towards the West had not been taken into serious consideration by Russia. Therefore, the Russian approach led these states to be a part of Western institutions such as the EU and NATO. Eventually, Bulgaria and Romania's accession to the NATO (2004) and the EU (2007); Colored Revolutions in Georgia in 2003 and Ukraine in 2004, and, the war in Georgia in 2008 further indicated the eagerness of the regional countries to be a part of the West.

Since the 1990s, the EU has been involved in the region through funding national and regional reform programs. Its strategic interests in the region have grown extensively because of the membership prospects of Bulgaria, Romania and Turkey. After 2001, the EU has gradually started to develop foreign policies towards other states in the region. And the Black Sea region has become a part of European Neighborhood Policy since 2003. As one of the most important projects of the EU, the European Neighborhood Policy contains the Black Sea region as a whole. The EU's initiatives in the Black Sea region are welcomed by the Black Sea littoral states as well. Bulgarian and Romanian accession to the EU at the beginning of 2007 was seen as a first step in the goal of integrating the Black Sea region into the Western world.

The membership of the two Black Sea countries, Romania and Bulgaria, was the turning point for the politics and security of 
the Black Sea region. At the same time, the US Department of Defense decided to devise a Black Sea Security Strategy. ${ }^{3}$ In seeking greater engagement with Black Sea states, Washington planned to use military aid as incentive to encourage regional security cooperation. ${ }^{4}$ Moreover, in the same year, the Black Sea region also gained an important place in the Euro-Atlantic security structure. In Istanbul meeting of NATO, the region was accepted as an essential part of Euro-Atlantic security. ${ }^{5}$

Black Sea states are now a part of the wider European security system. With the EU and NATO enlargements, the link between the stability of the Black Sea region and European security has become stronger. NATO recently started Active Endeavour and Black Sea Harmony operations in the Black Sea and Turkey has become the most active state in these operations. From 2004 till now, the US has been increasingly interested in the Wider Black Sea security issues.

In the 2008 Georgian war, US navy came into the Black Sea to provide humanitarian aid to Georgia. After the war between Russia and Georgia and the inability of NATO allies to assist Georgia, Black Sea's geostrategic significance increased in the eyes of international actors. Turkish Straits and the clauses of Montreux Convention, which manages the passage through the straits, were largely discussed in the international agenda. With Turkish and Russian insistence on the 21 days clause in the Montreux Convention, the US navy had to leave the Black sea region. These events were a clear indication of the increasing US interests in the Black Sea region.

Currently, the politics of the Black Sea region is mainly dominated by three issues; security, energy, and democratization. Since the end of the Cold War, regional cooperation across the

\footnotetext{
${ }^{3}$ Konoplyov, Ibid., p. 33.

${ }^{4}$ Idem.

${ }^{5}$ North Atlantic Treaty Organization, 28 June 2004, NATO Istanbul Summit Communique, <http:/ / wmw.nato.int/docu/pr/2004/p04-096e.htm>.
} 
A General Assessment on the Developments in the Black Sea Region

Black Sea has been growing steadily. Trade and economic interaction, travel and human contacts have increased dramatically. ${ }^{6}$ Among these areas, energy attracts the most attention for obvious reasons in international politics and it is also a geopolitical factor in the Black Sea region. Russia and Azerbaijan are energy producers, while Georgia, Ukraine and Turkey are transit countries. Especially, Russia has emerged as the dominant player in terms of using energy resources as a foreign policy tool. The US and the EU prefer the energy transportation lines to bypass the Russian territories to lower the EU's energy dependence to Russia. Russia used energy prices to affect international politics in regional countries, particularly in Ukraine and Georgia. In 2006 and 2009, the dispute between Russia and Ukraine led to the disruption of the gas supply to Europe, which caused a political crisis between Russia, Ukraine and the EU. Especially after the suspension of Russian natural gas deliveries to Ukraine, energy security became a priority for the EU.

As an important regional actor, Turkey has been very active in leading BSEC policies after the end of the Cold War. It also led the initiative to establish the Black Sea Naval Cooperation Task Group (BLACKSEAFOR). One of the most important issues is the status of the Straits and the Montreux Convention. Russia and Turkey, despite having divergent interest in some issues such as the pipeline projects, have found common ground in opposing the revision of the Montreux Convention. ${ }^{7}$

To sum up, Black Sea region, Wider Black Sea Region in the terminology of the EU, is becoming more important within the new global order along with the growing significance of energy security and liberalization processes. The region remains to be a

${ }^{6}$ Oleksandr Pavliuk, "Conclusion", The Black Sea Region: Cooperation and Security Building, eds. Oleksandr Pavliuk and Ivanna Klympush-Tsintsadze, New York, East West Institute, 2004, p. 292.

${ }^{7}$ See, Hurriyet Daily News,

<http:// wmw. burriyet.com.tr/english/world/9759360.asp?scr=1>, (access date: 04 April 2011). 
place of competing forms of regionalism. The EU and the US will continue to buttress the further integration of the Black Sea region to the West. Finally, Black Sea region is on the right way to create a common sense of regionalism and to sketching a joint security strategy. It can be said that as long as energy security remains to be a crucial issue in international politics, the global actors' interest in the Black Sea region will not diminish. 